\title{
Food and Nutrition Promotion: Feasibility of the Zimbabwe Agenda for Sustainable Socio-Economic Transformation
}

\author{
Promise Zvavahera (Corresponding author) \\ National University of Science and Technology, Zimbabwe \\ Tel: 263-773-471-703 or 263-4-706-515Ｅ-mail: promisezvavahera59@gmail.com
}

\section{Farai Chigora}

Lecturer at Catholic University of Zimbabwe, Zimbabwe

Tel: 263-772-886-871Ｅ-mail: fchigora@yahoo.com

Received: May 7, 2015 Accepted: May 26, 2015 Published: June 11, 2015

doi:10.5296/bmh.v3i1.7800 URL: http://dx.doi.org/10.5296/bmh.v3i1.7800

\begin{abstract}
Zimbabwe has faced persistent droughts from around year 1990 to date posing a structural food security challenge to the populace. Recently, the government of Zimbabwe introduced a blue print to spearhead and map sustainable balance in tapping value from the available natural and man-made resources in the country. This is known as the Zimbabwe Agenda for Sustainable Socio-economic Transformation Programme (Zim Asset). Amongst its prospects, agriculture and nutrition has been reckoned as a sustainable cluster for economic development. This study was undertaken one and half years after the implementation of Zim Asset as an evaluation mechanism on the successes and challenges faced in transforming the Zimbabwean economy with specific reference to the Food and Nutrition Cluster. The study employed both post positivism and interpretivism philosophies applying quantitative and qualitative approaches in gathering research data. The research instruments included documentary evidence, face to face in-depth interviews and focus groups. The in-depth interviews explored issues to do with resources allocation in line with the Zim Asset agriculture sustenance objectives. Focus was therefore, on the four Ministries supporting the Food and Nutrition Cluster. Eighty percent of the respondents reported that the economic blue print has not made any significant strides in improving the country's agricultural performance and food security since the inception of Zim Asset in October 2013. It was noted that the country continued to import maize from Zambia
\end{abstract}




\section{Macrothink}

Business and Management Horizons

ISSN 2326-0297 2015, Vol. 3, No. 1

and other countries in the region. The major reason for its lack of success was due to the unavailability of resources to support the programme and the fact that land was allocated to unproductive and cell phone farmers. There was consensus that land audit and recapitalisation of the agriculture sector were critical in achieving the desired outcomes. The study recommends that the programme be adequately funded, so that the country can become self-sufficient.

Keywords: Zim Asset, socio-economic transformation, economic growth, food security 


\section{Introduction}

Zimbabwe has undertaken a number of economic turn-around programmes since independence in 1980, with the aim of improving the socio-economic status of its citizens through equal distribution of resources. Some of the economic policies which were undertaken between 1980 and 2012 are the Economic Structural Adjustment Programme (ESAP) (1990s), the ZIMPREST (1998-2002), The Ten Point Plan (2002), the Millennium Economic Recovery Programme (MERP, 2000), Short to Medium Term Strategy (STERP) (2009), the National Economic Revival Programme NERP (2003), (Kanyenze \& Kondo, 2011) and more recently Zim Asset. Zim Asset is considered to be poised for success because it is designed to streamline development from household level to national level through concerted efforts by all stakeholders. It is emanating as a government and key-stakeholder machinery oiled to favourably positioning the socio-economic development of the country towards equity and valuable returns. Resources are always in short supply in relation to human needs and wants such that the Zim Asset focuses on their equal distribution with the future generations in mind. Therefore, sustainable use of the country's vast natural and human resources have been identified as critical in unlocking the country's potential to revive the economy. The poor performance of the Zimbabwean economy has been attributed to political upheavals, natural disasters like droughts, epidemic diseases such as cholera, poor debt management and imposed sanctions which affected the country's ability to trade on the international market. The land reform program of 2000 led to the land redistributed from the minority whites to the majority indigenous blacks with an equity-socialism agenda. This ignited chaos and break of socio-economic ties between Zimbabwe and the Western communities restricting trade and identity of locally produced products in their traditional markets. These issues led to mystification as economic leaders formulated one policy to another haphazardly without any implementation. Also many of these policies lack stakeholder involvement such that no maximum support is given especially by the public. The Zim Asset has been designed with a motive to capture the desires and gain progress from all stakeholders including the public at large. It has been given maximum publicity by government authorities, news agencies and educational institutions.

\section{Zim Asset in Perspective}

After the 31 July 2013 general elections, the Government of Zimbabwe embarked on a five year programme (2013-2018) which is meant to transform the economy by crafting the new economic policy, the Zimbabwe Agenda for Sustainable Socio-economic Transformation (Zim Asset). The vision of Zim Asset is "Towards an Empowered Society and a growing Economy” (Zim Asset, 2013). Zim Asset includes four clusters namely:

- $\quad$ Social Services and Poverty Reduction;

- Value Addition and Beneficiation;

- Food Security and Nutrition; and

- Infrastructure and Utilities (Zim Asset, 2013). 
Zimbabwe has vast natural resources some of which are untapped (Zim Asset, 2013). The recent discoveries of diamonds and other minerals have given Zimbabwe a global competitive and strategic position on the world market. The spirit and belief is that the economy is going to be grown from local resources and external funding from friendly countries. The country has gone to the extent of considering outside financing for the programme from its long-time allies. Countries considered to fund this programme are Brazil, Russia, India, China and South Africa (BRICS), (Zim Asset, 2013). A statement by the former Minister of Finance indicated that a holistic and multi-faceted approach is what is required to achieve the desired goals to grow the economy. Foreign direct investment is also critical for injecting the much needed liquidity on the financial market (Mapauranga, 2014).

Zim Asset has also proposed quick wins in all the four clusters by 2015. The understanding is that these quick wins have to be achieved within one year from time of implementation of Zim Asset and these will support other programmes and projects to gather moment by providing financial resources in order to achieve the national goals of growing the economy by 2018. The predecessors of Zim Asset did not achieve the desired results of improving the performance of the economy because of lack of financial support and inadequate supporting legal framework (Kanyenze \& Kondo, 2011).

The focus of this study is on the Food and Nutrition Cluster. This is so because the Zimbabwean economy is based on agriculture. Agriculture is responsible for improving the food security and nutrition for the country. Climate change has caused cute food shortages for more than two decades in a row (Kanyenze \& Kondo, 2011). Kanyenze and Kondo (2011) aver that Zimbabwe's economy is still agriculture based. The World Bank Development Report (2008) indicated that agriculture can be a vehicle for economic growth as evidenced by many European countries.

The Food and Nutrition Cluster is responsible for making sure that the country has sufficient food and food reserves for its population. Zimbabwe through Zim Asset seeks to reclaim its position as the best farming country in Southern Africa. This cluster is informed by the Draft Comprehensive Agriculture Policy, SADC and COMESA Food and Nutrition Policy Framework (2012-2032), the Comprehensive African Agricultural Development Programme (CAADP) and the Zimbabwe Agriculture Investment Plan, (2013-2017) (Zim Asset, 2013). The recapitalisation of AgriBank, the Grain Marketing Board (GMB), and the Agricultural Rural Development Authority (ARDA) are critical since they are the drivers of Zim Asset agenda within this cluster. Adequate food and nutrition are key to peace and security. This sector needs to remain viable. The Zim Asset document (2013) clearly states that the re-establishment of support to farmers will enhance productivity. The growth in the agriculture sector is underpinned by:

- Rehabilitating and expanding of the irrigation system;

- Resuscitating existing dams and the construction of new ones throughout the country;

- Inputs should be made available and affordable on time;

- Government to consider agriculture as a critical sector of the economy; 


\section{Macrothink}

Business and Management Horizons

ISSN 2326-0297

2015, Vol. 3, No. 1

- Strengthening and capacitating financial institutions so that they fund agriculture;

- Increasing contract farming arrangements for the farmers so as to build capacity (Zim Asset, 2003);

The Food and Nutrition Cluster is made of the following four Ministries:

- Environment, Water and Climate;

- Women Affairs, Gender and Community Development;

- $\quad$ Agriculture, Mechanisation and Irrigation Development; and

- Lands and Rural Resettlement.

\section{Objectives of the Study}

The aim of the study was to evaluate the effect of Zim Asset on improving food security and nutrition for the country. The specific objectives of the study were to:

- Identify the milestones made by the implementation of Zim Asset in the Food and Nutrition Cluster from October 2013 to March 2015;

- Identify challenges in the implementation of the programme; and

- Make recommendations for the successful implementation of the programme.

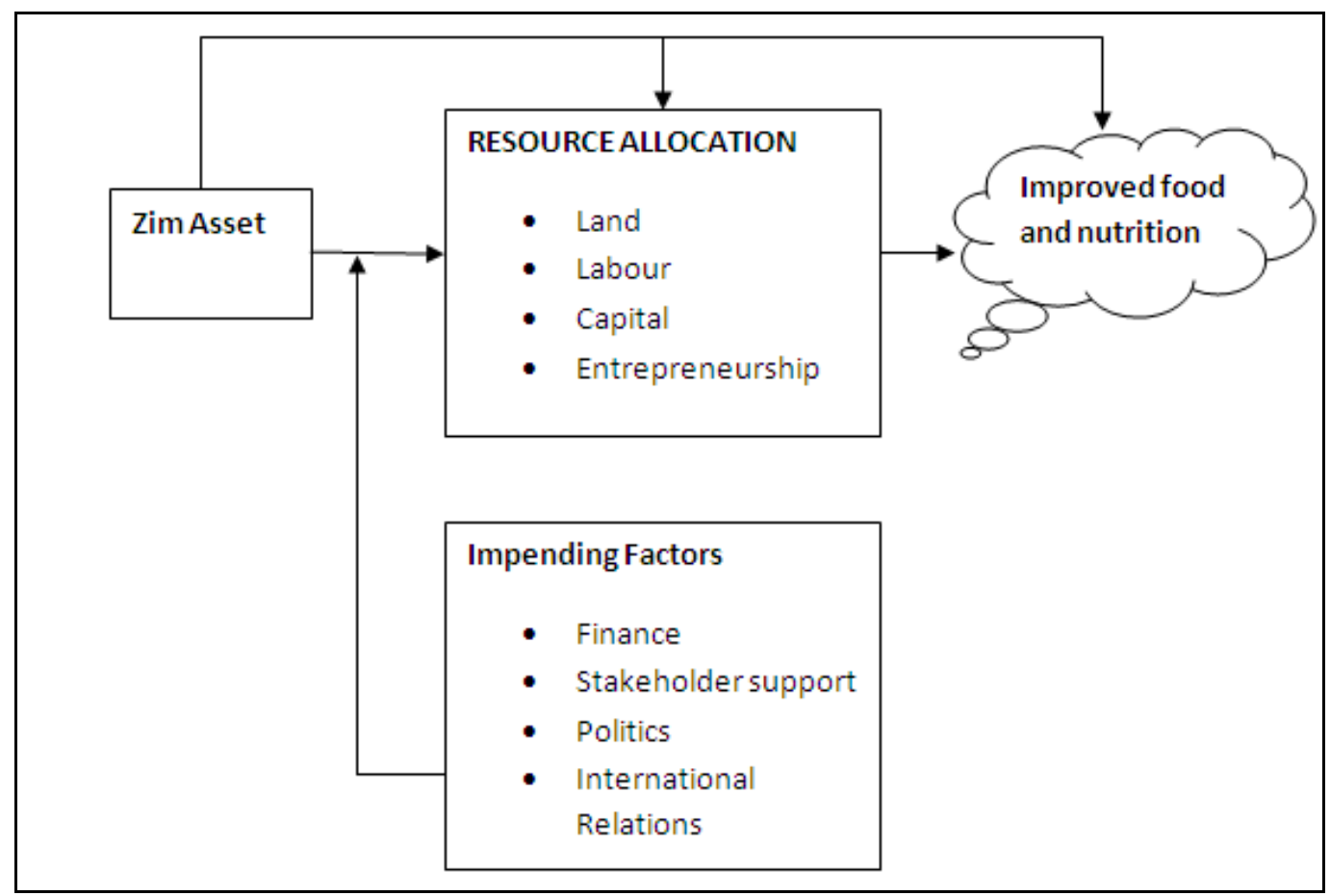

Figure 1. Research proposition

Source: Research design. 


\section{Macrothink

The research proposition in figure 1 denotes that there is a direct relationship between Zim Asset and improvement in food and nutrition. However, there is a moderating factor in the relationship that is resources allocation (land, labour, capital and entrepreneurship). It is when the Zim Asset is implemented with adequate land, labour, capital and entrepreneurship that it will achieve an improvement in the Food and Nutrition Cluster. The achievement is also disturbed by various factors which include lack of finances, lack of stakeholder participation and support, politics and international relations.

\section{Research Methodology}

This study was carried out in April 2015 involving four Line Ministries in the Food and Nutrition Cluster. The population of this study was made of all farmers in Zimbabwe and all employees in the four line Ministries. Purposive sampling was applied to involve all (32) Directors and Deputy Directors in the four Ministries. This method was used because it allows the researcher to get comprehensive and rich information from senior government officials who are the drivers of the programme. The researchers came up with two focus groups of twenty five farmers each in Ward 6 of Mazowe District in Mashonaland Central Province. The focus groups included both 1A (12 hectares) farmers and A2 farmers (12 hectares and above). The sample of this study was therefore 82.

\section{Findings}

\subsection{Ministry of Agriculture, Mechanisation and Irrigation Development}

Vital information was obtained from reports from the Ministry of Agriculture, Mechanisation and Irrigation Development on the statics on land under maize and inputs given to farmers through various schemes. Information on the growth projections on agriculture from 2013-2018 was obtained from the Zim Asset document.

\subsubsection{Agricultural Inputs Support}

The Ministry is also responsible for distributing free inputs to farmers through the Government Smallholder Input Support Facility. Contracting farming also availed inputs to farmers. Other inputs were also distributed through the Presidential Scheme throughout the country. The major setback on the part of farmers was late distribution and inadequate inputs. The table below show the types and quantities of inputs which were distributed to farmers. 


\section{Ml Macrothink}

Business and Management Horizons

ISSN 2326-0297

2015, Vol. 3, No. 1

Table 1. The government input programme

\begin{tabular}{|c|c|c|c|c|c|}
\hline \multirow[t]{2}{*}{ Input } & \multicolumn{3}{|c|}{ Quantity (MT) } & \multirow{2}{*}{$\begin{array}{l}\text { Quantity per } \\
\text { household ( kg ) }\end{array}$} & \multirow{2}{*}{$\begin{array}{l}\text { No. of } \\
\text { beneficiaries }\end{array}$} \\
\hline & Contracted & Supplied & $\%$ & & \\
\hline Maize seed & 15,955 & 5,921 & 37 & 10 & 592,100 \\
\hline Sorghum seed & 403 & 208 & 52 & 5 & 41,600 \\
\hline Millet & 76 & 40 & 53 & 5 & 20,000 \\
\hline Soyabeans & 800 & 40 & 5 & 2 & 2,000 \\
\hline Cow peas & 245 & 113 & 46 & 2 & 56,500 \\
\hline Cotton Seed & 3,000 & 310 & 10 & 10 & 31,000 \\
\hline Cotton Chemicals (l) & 60,206 & 43,214 & 72 & & \\
\hline Cotton Chemicals (Mt) & 61 & 45 & 74 & & \\
\hline Compound D & 72,496 & 31,382 & 43 & 50 & 627,640 \\
\hline Top dressing & 58,150 & 15,304 & 26 & 50 & 306,080 \\
\hline
\end{tabular}

Source: (Ministry of Agriculture, Mechanisation and Irrigation development First Round Report, 2015).

\subsubsection{Contract Farming}

On tobacco, private organisations contracted farmers to grow 72,756 hectares of tobacco in the 2014/15 season. On the other hand cotton farmers were contracted to grow 201,678 hectares of cotton. Soyabeans companies financed farmers to grow 8000 hectares of this crop to the tune of \$US5million (Ministry of Agriculture, Mechanisation and Irrigation development First Round Report, 2015). The diagram further illustrates areas that were put under maize by province for the period under review.

Table 2. Maize by time of planting

\begin{tabular}{|l|l|l|l|l|l|l|l|l|}
\hline Province & $\begin{array}{l}\text { Planted } \\
\text { area (ha) }\end{array}$ & $\begin{array}{l}\text { November } \\
\text { \% }\end{array}$ & $\begin{array}{l}\text { December } \\
\text { \% }\end{array}$ & $\begin{array}{l}\text { January } \\
\text { \% }\end{array}$ & $\begin{array}{l}\text { Planted } \\
\text { area (ha) }\end{array}$ & $\begin{array}{l}\text { November } \\
\text { \% }\end{array}$ & $\begin{array}{l}\text { December } \\
\text { \% }\end{array}$ & $\begin{array}{l}\text { January } \\
\text { \% }\end{array}$ \\
\cline { 2 - 10 } & $\mathbf{2 0 1 4 / 1 5}$ & $\mathbf{2 0 1 4}$ & $\mathbf{2 0 1 4}$ & $\mathbf{2 0 1 5}$ & $2013 / 14$ & 2013 & 2013 & 2014 \\
\hline $\begin{array}{l}\text { Mashonaland } \\
\text { West }\end{array}$ & 223,251 & 29 & 59 & 12 & 265,714 & 41 & 51 & 8 \\
\hline $\begin{array}{l}\text { Mashonaland } \\
\text { Central }\end{array}$ & 182,894 & 6 & 84 & 10 & 193,320 & 19 & 72 & 9 \\
\hline $\begin{array}{l}\text { Mashonaland } \\
\text { East }\end{array}$ & 191,335 & 31 & 63 & 6 & 211,972 & 56 & 40 & 4 \\
\hline Manicaland & 216,469 & 31 & 57 & 12 & 217,648 & 48 & 43 & 9 \\
\hline Midlands & 291,443 & 28 & 57 & 24 & 351,829 & 31 & 54 & 15 \\
\hline Masvingo & 193,183 & 26 & 50 & 41 & 216,062 & 33 & 40 & 26 \\
\hline $\begin{array}{l}\text { Matabeleland } \\
\text { North }\end{array}$ & 129,796 & 20 & 60 & 20 & 137,246 & 23 & 61 & 15 \\
\hline $\begin{array}{l}\text { Matabeleland } \\
\text { South }\end{array}$ & 101,995 & 24 & 56 & 20 & 127,239 & 29 & 51 & 20 \\
\hline Total & 1,531663 & 25 & 61 & 14 & 1,721030 & 36 & 51 & 13 \\
\hline
\end{tabular}

Source: (Ministry of Agriculture, Mechanisation and Irrigation development First Round Report, 2015). 
The focus groups submitted that they had heard about the commissioning of the 15 irrigation schemes throughout the country by April 2015 so as to boost maize production. The government through the of Ministry of Agriculture, Mechanisation and Irrigation Development approved that private Grain Millers import 600,000 tones of maize to help improve the food situation in the country (Sunday Mail 5 April, 2015). The last exports which were realised by the country were in May 2014 from tobacco and minerals sales but however, there is still a huge deficit (Treasury State of the Economy Report, 2014). Even though all the farmers indicated that they received inputs from the Presidential Scheme, they were said to be inadequate and did not come on time.

\subsection{Ministry of Environment, Water and Climate}

The thrust of Ministry of Environment, Water and Climate is to strengthen collaboration with communities in sustainable utilisation of natural resources. Most rural communities live on the exploitation of natural resources such as selling of wild fruits, fish, fire wood and wood curving. Communal Areas Management Programme for Indigenous Resources (CAMPFIRE) model was put in place by the government to enable locals to benefit from their local resources including wildlife to promote rural development. It also involves safari hunting which is more profitable than other ventures. CAMPRE uses the participative approach. Due to poverty and poor economic performance of the economy, there has been an increase pressure on exploitation of natural resources. CAMPFIRE is collaboration between communities and Rural District Councils on the utilisation of natural resources in their areas (http://link.springer.com/article/10.1007\%2Fs10531-009-9612-8). The Ministry has been a given a directive by the Cabinet to take all conservancies which are being mismanaged or in conflicts and give them to Zimbabwe Parks and Wildlife Management Authority. Some joint ventures in this area have also been successful. The Ministry of Environment, Water and Climate through the Department of Water Resources Management has proposed the construction of new dams so that agriculture is improved. The Ministry's responsibility is to bring the water to the edge of the fields and then the Ministry of Agriculture, Mechanisation and Irrigation Development takes the water to the farmers for irrigation purposes.

\subsection{Ministry of Women Affairs, Gender and Community Development}

The objective of the Ministry in food security is to make sure that rural communities through small-scale farmers produce sufficient food at household level and even deliver the excess to GMB. This Ministry is responsible for empowering the vulnerable groups in society and many projects have been running. These projects have to a greater extent improved the livelihoods of rural communities. Women and other vulnerable groups have benefited from these government initiatives. Even though some of these projects were started well before Zim Asset they are helping to support Zim Asset so that it remains on the right track by providing financial resources and expertise in running projects. The Ministry is also providing agricultural inputs to rural communities so that they can participate in economic activities thereby improving their livelihoods. Responses from the focus groups indicated that the approach is plausible as it has high changes of improving food security at household level. (http://www.women.gov.zw/site-map/80-programmes-update/88-food-security). The Ministry 
is also promoting community gardens so as to improve on nutrition. These community gardens focus on a wide range of vegetables and herbs which enhance the health well-being of communities. There are many other projects which are going on such as cattle and chickens rearing.

\subsection{Ministry of Lands and Land Resettlement}

This Ministry is responsible for land redistribution in the country. The current challenge is that the resettled farmers do not have the security of tenure. This means that the farmers do not have the tittle to the pieces of land they are occupying. The Justice for Agriculture Commission indicated that 8million is needed to compensate the former white farmers so that the land cases be put to rest (http://www.thepatriot.co.zw/old_posts/what-is-zim-asset-part-two/). Even though the white farmers were removed out of their farms, they still have the title deeds. Another contentious issue is multiple farm ownership by Senior Government Officials, prominent people and politicians at the expense of the majority. Land audit could be an answer to this. Another issue is failure by most farmers to fully utilise the land.

Even though the Government had projected growth targets, these were difficult to achieve due to various challenges. Table 3 below shows the projected growth targets in the Food and Nutrition Cluster.

Table 3. Growth targets for Zim Asset (2013-2018)

\begin{tabular}{|l|l|l|l|}
\hline Year & $\begin{array}{l}\text { Agriculture, hunting and fishing. } \\
\text { Projected growth (\%) }\end{array}$ & $\begin{array}{l}\text { Electricity and water. } \\
\text { Projected growth (\%) }\end{array}$ & $\begin{array}{l}\text { Public Administration. } \\
\text { Projected growth (\%) }\end{array}$ \\
\hline 2013 & -3 & 4.2 & 3.2 \\
\hline 2014 & 9.0 & 4.5 & 4.2 \\
\hline 2015 & 5.1 & 7.0 & 4.5 \\
\hline 2016 & 7.0 & 9.8 & 3.5 \\
\hline 2017 & 8.0 & 11.0 & 2.4 \\
\hline 2018 & 12.5 & 16.0 & 2.5 \\
\hline
\end{tabular}

Source: Zim Asset (2013).

Table 3 shows that the agricultural produce is projected to increase to $9 \%$ in 2014 from $-3 \%$ in 2013. However, a survey that was carried out by the Ministry of Agriculture, Mechanisation and Irrigation Development showed that this year (2015) is a write off due to the late and erratic rains received so far. In terms of electricity and water supply, focus groups highlighted the need to engage the Zimbabwe National Water Authority and ZESA in order to address power cuts and water supply to farmers who are engaged in winter agriculture to continue undisturbed. However, the assertions by Mapauranga (2014) that farmers should not be given free or subsided agricultural inputs will defeat the whole purpose of empowering farmers and capacitating the sector to improve on their produce. Mapuranga (2014) argues 
that this will give fiscal space to Treasury which is battling to meet other financial obligations such as health, salaries for civil servants and social services which are an eye sore to the nation. However, looking at the food situation, the government needs to invest more in agriculture. Most of the crops which have high nutritional values are either delivered in very small quantities or are not delivered at all. It is a pit to note that crops such as Rapoko (zviyo), groundnuts, roundnuts (Nyimo) and many others are delivered in very small quantities compromising nutritional value. Most farmers rely on agriculture as their sources of livelihoods and since this season has been declared a drought, most people are going to starve and nutrition to a larger is compromised.

The First Round Report (2015) by the Ministry indicated that rainfall distribution was poor in space and time across the country except in the northern parts of Mashonaland Central (Rushinga, Mbire, Lower Muzarabani and lower Mt Darwin) and parts of Mashonaland East (Uzumba Maramba Pfungwe and Mudzi). The first rains were followed by a long dry period leading to poor germination and severe moisture stress for the early crops. Though the central and southern parts of the country had an early start to the season, the benefits were offset by poor distribution of rainfall in the season. Persistent and heavy rains were received across the country from the last week of December 2014 to the second week of January 2015. Floods were experienced in low lying areas of the Zambezi valley (Ministry of Agriculture, Mechanisation and Irrigation development March Report, 2015). A report from Famine Early Warning System Network (2015) predicated that the 2014-2015 agricultural season was a write off.

Responses from the focus groups indicated that the majority of them lacked understanding on what Zim Asset is all about and what it intends to achieve. The interview responses from senior government officials revealed that similar programmes were mooted in the previous years and these did not yield the desired results due to lack of funding and policy coherence. Some of the senior government officials (56\%) indicated that corruption could also be one of the setbacks in achieving the programme's goals. Inputs which were meant for farmers in some cases did not reach the intended beneficiaries. Responses from focus groups and senior government officials revealed that Zim Asset has not shown signs of improving the Food and Nutrition Cluster. Ninety nine percent (99\%) of the respondents from senior government officials indicated that there was food insecurity due to the erratic rains received during the season. There is no evidence to show that friendly countries which were reported to support the programme were forthcoming. They indicated that they did not understand how it was different from its predecessors. All the respondents indicated that the drought was going to affect income at both national and household levels since most rural people survived on agriculture. One farmer had this to say 'The cost of inputs especially on maize production does not translate to what one gets after selling the produce to the Grain Marketing Board'.

Erratic electricity and water supplies were also mentioned as setbacks especial to farmers who were engaged in winter crops and practise farming throughout the year. On the way forward, farmers indicated that they needed the 99 year leases to be bankable so that they can use them to get loans from banks and other financial institutions. All the respondents further indicated that that GMB needed to be financially capacitated so that it could pay farmers on 
time and provide all inputs and other services at affordable prices to farmers. All the respondents indicated that the government should engage ZESA so that it can supply electricity all the time since some farmers were engaged in winter crops such as wheat.

\section{Discussion}

The news that the country will commission 15 irrigation schemes by the end of April (2015) by the Ministry of Agriculture, Mechanisation and Irrigation Development has been received with great joy by most respondents as these are likely to improve on food security and nutrition. Currently, there is very small land which is under irrigation in the country since much of the irrigation system was vandalised during the land invasions of 2000. The construction of new dams and the rehabilitating of the existing ones will also go a long in boosting the irrigation endavour and improve food security and nutrition. The vision of Zim Asset "Towards an Empowered Society and a growing Economy" (Zim Asset, 2013) is contrary to the findings of the study. According to the findings of this study, people received very little in terms of inputs from the government. Without adequate funding of the sector, it will be very difficult to improve the food and nutrition situation in the country. It is prudent for the government to capacitate this critical sector of the economy. Without adequate food there is no peace and tranquillity. It is just rhetoric by the government to say that Zim Asset is going to grow the economy yet there are no resources to support the programme. Resources and political will are the critical drivers of this programme. It is very difficult to progress without direct invest to boost the liquidity crisis facing the country. The chances of its failures like its predecessors are very high as there are not activities on the ground to show that some work is being done. Increased agriculture production is key to food security and nutrition. Zim Asset has not started new projects due to lack of funding but has been trying to strengthen the existing ones. The Ministry has also taken all conservancies which are under disputes or being underutilised so as to empower local communities. It has been noted that no funding has come from BRICKS to support the programme as yet. The efforts by the four Ministries in the cluster show that at least some projects such as CAMPFIRE, the input schemes and projects for women and the under privileged are under way throughout the country (http://link.springer.com/article/10.1007\%2Fs10531-009-9612-8,

http://www.women.gov.zw/site-map/80-programmes-update/88-food-security). This brings back the memories of 2008, when the country was faced with serious food shortages which led to strikes and unrest in the country. What is worrisome is that the GMB is failing to provide adequate inputs to farmers on time and also failing to pay for grain delivered. The GMB's depots around the country have very little resources to last for even a month. The findings of this study are in agreement with the report by the Famine Early Warning System Network (2015), which predicated that the 2014-2015 agricultural seasons is a write off. The fact that the government has given green light to millers to import maize so as to improve food security is a sign that all is not well in the agriculture sector. The Presidential Input Scheme complemented the Government Smallholder Input Support Facility. The Quantities which were given by Government can only improve food security at household level in the peri-urban and backyard farming (Ministry of Agriculture, Mechanisation and Irrigation Development First Round Report, 2015). 
On the way forward, farmers indicated that they needed the 99 year leases given by the Government to A2 farmers to be bankable. All farmers submitted that the inputs from the Presidential Scheme needed to be distributed on time and in the right quantities. They further indicated that that GMB needed to be capacitated so that it can pay farmers on time. All farmers noted that it is critical for the Government to capacitate GMB. Small grains such as groundnuts, roundnuts rapoko and many others were no longer being delivered to GMB in large quantities thereby compromising the health of many children (table 2). For the period under review, no was delivered to GMB. The Government through the Ministry of Agriculture, Mechanisation anal Irrigating Development should be encouraged to make sure that farmers are given inputs on time in order to improve food security and nutrition. What remains as a challenge are the food reserves for the country.

\section{Recommendations}

There is need for a well-structured corporate governance system which should clearly elaborate the requirements of every stakeholder and consequences to any misappropriation of resources. This is so because corruption has taken precedence in the implementation of previous economic policies and Zim Asset is not spared either, affecting its potential to improve economic welfare of the general public.

Audits to assess maximum participation of every stakeholder should be applied. This is because the program is highly involving with various individuals and organisations dependent on each other for prosperity. Therefore, stakeholder involvement should be improved to achieve the goals of the Food and Nutrition Cluster.

The Presidential Input Support Scheme should be reinforced and make sure that this programme is sustained and cascaded to household levels. Farmers need also to be protected from scrupulous contract farming organisations which are reaping farmers by offering them very low prices. The GMB should also pay farmers who deliver their grain to them as it encourages hardworking with returns and farmers are likely to be innovative in their processes when they prospect a high equity. The government should evaluate every economic programme after its life span and make the results public and this informs future programmes planning and resources allocation.

Funding must be made available if the government is to achieve its desired goals and objectives of growing the economy by 2018. Planning without resources, especially funding at national is catastrophic. It is also critical to appraise the general public on the successes or failures of national programmes so that they improve on future programmes and projects. It is true that the country still relies on rain fed agriculture and it needs to be supplemented by irrigation. However, farmers who use irrigation should be encouraged to pay their bills on time or make some payment plans. The various schemes which provide inputs to farmers should increase quantities, otherwise food insecurity will remain challenge.

\section{Conclusion}

Zim Asset is a promising economic policy if it is fully implemented and supported. It is critical for countries to come up with implementable economic policies which bring the 
desired results. Zim asset came at the right when the country was rallying with poverty and nutrition challenges and importing maize and other grains from the region. What could be lacking from Zim Asset is financial support because up to date some government Ministries are still at the planning stage and others are even ignorant about the programme. Monitoring and evaluation of all programmes and projects have to be a prerequisite if success is to be achieved. No information is made available to the general public on the performance of economic policies so that they can make informed decisions and come up with better plans in the future.

\section{References}

Brett, E. A. (2011). State failure and successes in the Uganda and Zimbabwe: The Logic of Political Decay and Reconstruction in Africa. [Online] Available: http://sempa.wordpress.com 2011/05/22014

Economic_history_of_Zimbabwe. [Online] Available: http://Wikipedia.org/wiki/

Kanyenze, G., \& Kondo, T. (2011). Beyond the Enclave: Towards a Pro-Poor and Inclusive Development for Strategy for Zimbabwe.

Mapauranga, $\quad$ S. $\quad$ (2014). $\quad$ OOnline] Available: http://www.thezimbawean.co/news/Zimbabwe.biti-proposes-solutions

Ministry of Agriculture, Mechanisation and Irrigation Development. First Round Crop and Livestock Assessment Report 2014/15 Season, Zimbabwe.

Nick Mangwana Zimbabwe: Zim-Asset one year on-successes and misses.

Report from Famine Early Warning System Network. (2015). [Online] Available: http://reliefweb.int/report/malawi/southern-africa-food-security-alert-january-5-2015

Sichone, O. (2003). Zimbabwe Economic Polices, 1980-2002. DPMN Bulletin, X(2).

The Sunday Mail. (2015). Food security: Private sector to import maize.

The Zimbabwean 8 September. (2014). Zimbabwe's economic future uncertain. World Bank.

Treasury state of the economy report: May 2014 Ministry of Finance and Economic Development.

World Bank. (2008). The Growth Report: Strategies for Sustained Growth and Inclusive Development. Washington, DC: World Bank, Commission on Growth and Development.

Zimbabwe Agenda for Sustainable Socio-Economic Transformation (Zim Asset). Towards an Empowered Society and a Growing Economy, October 2013-December 2018.

Zimbabwe Medium Term Plan. (2011-2015).

http://link.springer.com/article/10.1007\%2Fs10531-009-9612-8

http://www.thepatriot.co.zw/old_posts/what-is-zim-asset-part-two/ 


\section{Macrothink}

Business and Management Horizons

ISSN 2326-0297

2015, Vol. 3, No. 1

http://www.women.gov.zw/site-map/80-programmes-update/88-food-security

\section{Copyright Disclaimer}

Copyright for this article is retained by the author(s), with first publication rights granted to the journal.

This is an open-access article distributed under the terms and conditions of the Creative Commons Attribution license (http://creativecommons.org/licenses/by/3.0/). 